\title{
PANORPIDÆ FROM CHINA (MECOPTERA) ${ }^{1}$
}

\author{
By F. M. Carpenter \\ Harvard University
}

Among the Chinese Panorpidæ in the Museum of Comparative Zoology there are several specimens which were not treated in my previous paper on Mecoptera from China. ${ }^{2}$ Most of these were collected by Gaines Liu in Anhwei and Szechwan Provinces, but a few were obtained by L. Gressitt in Kiangsi and Kwantung. They form the basis of the present paper, which also includes the description of a new species in the U. S. National Museum, and notes on Navas' types in the Muséum National in Paris.

\section{Genus PANORPa Linn.}

Including the two described below, nineteen species of this genus are known from China.

Panorpa obliqua, n. sp.

Plate 10, fig. 2, 3, 8; plate 11, fig. 9.

Body brown, with the vertex, thoracic nota and abdominal tergites very dark brown. Fore wing: length, $12 \mathrm{~mm}$.; width, $3.5 \mathrm{~mm}$; membrane faintly yellow, markings brown; apical ${ }^{3}$ band greatly interrupted, maculate; pterostigmal band complete, connecting with a more proximal band to form a large "V" near the middle of the wing; basal band interrupted, consisting of a large rounded spot on the anterior margin, and an irregular patch along the posterior margin; 2nd basal spot well developed, first absent or very small; both marginal spots absent. Crossveins not margined. Hind wing: similar to the fore in markings, except that the left "arm" of the "V" is usually interrupted. Anal horn absent. of genitalia: genital bulb rounded, forceps

\footnotetext{
${ }^{1}$ Published with the aid of a grant from the Museum of Comparative Zoology at Harvard College.

${ }^{2}$ Proc. Ent. Soc. Wash., 1938, 40:267-281.

${ }^{3} \mathrm{I}$ have used here the same terminology for wing markings and genitalia as employed in my revision of the Nearctic Mecoptera (Bull. Mus. Comp. Zool., 1931, 72:205-277).
} 
short, outer margins slightly concave; prominent lobes on inner margin of forceps near the base; hypovalvæ short, uniting near the middle of the genital bulb, and extending slightly beyond the base of the forceps; ventral valves simple, each consisting of a slightly flattened process, with a few short barbs on inner surface distally, and terminating in a longer series of barbs directed inwards; preëiproct much narrowed distally, with a pair of broad terminal lobes, close together. $\%$ : internal skeletal plate of ninth segment large, with two long, slender distal processes and a pair of large, ear-like flaps laterally; the usual axis is short, but there is a very slender median process extending posteriorly.

Holotype ( $\hat{o}$ ): Museum of Comparative Zoology, no. 27325. Hong San, S. E. Kiangsi Province, China. June 28, 1936 (L. Gressitt).

Allotype: same collecting data as holotype, except for date June 29, 1936; in Museum of Comparative Zoology.

Paratypes: 1 i , same collecting data as holotype, except for date - June 30, 1936; in the Museum of Comparative Zoology.

This strikingly marked species is easily recognized by the oblique stripe traversing the middle of the wing, and extending posteriorly and distally from the anterior margin. The short hypovalvæ of the male genital bulb are unique among the known Chinese species of Panorpa, but are very much like those of certain Japanese and Siberian species (e.g., P. wormaldi MacL., preyeri MacL., etc.) to which obliqua is undoubtedly closely related. Certain North American species of Panorpa (e.g., lugubris Swed., nuptialis Gerst., rufa Gray) have similar hypovalvæ, but their other genital structures are very different from those of obliqua and the other Asiatic species indicated.

Panorpa tetrazonia Navas

Plate 10, fig. 1, 5, 6; plate 11, fig. 10.

Panorpa tetrazonia Navas, 1935, Notes d'Ent. Chin., Mus. Heude, 2 (5) :96, fig. 61 .

This species was based on a single male from Kuling, Kiangsi Province, and deposited in the Musée Heude, Shanghai. In the Museum of Comparative Zoology there are four males and five females which I consider to be this species. Four of these $(1$, 3 \% ) were collected in Taipingshien, Anhwei Province, China, October 1932 (G. Liu); and the others on Huang Shan, in 
Anhwei, only a few miles southwest of Taiping. These localities are only about one hundred miles from the type locality, Kuling, in northern Kiangsi Province.

The wing markings of the Anhwei specimens are identical with those shown in Navas' figure of the wing, and the general body structure fits his description. I have therefore redescribed the species here on the basis of the new specimens, although a study of the genitalia of the type will be necessary before the specific determination is certain.

Body light to dark brown, the thoracic nota and abdominal tergites being somewhat darker than the rest of the body. Fore wing: length, $12-13 \mathrm{~mm}$.; width, 3-3.5 $\mathrm{mm}$. Membrane faintly yellow, markings brown, apical band interrupted posteriorly and usually with a few small clear spots around the cross-veins; pterostigmal band complete, forked posteriorly; between pterostigmal and basal bands an elongate spot at anterior margin; basal band complete but slender; first basal spot present, second basal and both marginal spots absent. Cross-veins not margined. Hind wing: similar to the fore in markings, except that the basal band is interrupted and the first basal spot is absent. Anal horn absent. $\hat{o}$ genitalia: genital bulb oval; forceps moderately long, slender, the outer margins not concave; forceps with prominent lobes; hypovalvæ broad and short, not extending as far as the bases of the forceps; ventral valves conspicuous, each arising from a very slender stalk which widens abruptly and gives rise to a long curved process; the wide head of the stalk and the curved process bear numerous long barbs; preëiproct with a shallow distal concavity. $q$ : internal skeleton of ninth abdominal segment, with broad plate and short axis; anterior processes of plate slender and convergent distally.

Although the wing pattern of this Panorpa is not very distinctive, no other known Asiatic species has precisely the same markings. The male genital structures, especially the ventral valves, are most unusual, as is also the form of the internal skeleton of the ninth abdominal segment of the female.

Panorpa lutea, n. sp.

Plate 10, fig. 7; plate 11, fig. 11.

Body reddish brown, darker brown on vertex, thoracic nota and abdominal tergites. Fore wing: length, $15 \mathrm{~mm}$.; width, 3.5 mm. Membrane deep yellow or orange, markings dark brown; 
apical band separated by a wide hyaline stripe into a large anterior apical area and a small posterior spot; pterostigmal band entire, forked posteriorly; a short rectangular spot between the pterostigmal and basal bands; basal band complete and very broad; first basal spot present, second and both marginal spots absent. Cross-veins not margined. Hind wing: similar to fore wing in markings. $\%$ : internal skeleton of ninth abdominal segment small, with a very short axis and convergent posterior processes. of unknown.

Holotype ( 9 ): Museum of Comparative Zoology, no. 27326. Huang Shan, Anhwei Province, China (G. Liu). A second female (in poor condition) was collected on Kinhua Shan, Anhwei, China, October 1932 (G. Liu).

This strikingly marked species is unlike any other described Asiatic species of Panorpa. The male should be easily recognized by the orange color of the wings.

\section{Panorpa davidi Navas Plate 10, fig. 4.}

Panorpa davidi Navas, 1908, Mem. Real. Acad. Cienc. Barc., 1908: 415, fig. 19a,b. Esben-Petersen, Coll. Selys, 1921, 5(2) : 29, fig. 21-23.

The type of this Tibetan species has been redescribed and figured by Esben-Petersen (1921), but his drawing does not show clearly the characteristics of the male genital bulb. I therefore include here a figure of the genital bulb of the type which I made at the Muséum National in Paris in 1938. The hypovalvæ and ventral valves are slender and long, and the inner surface of the ventral valves bears a series of short barbs. At the base of the forceps the bulb itself gives rise to a prominent papilla, along the inner surface of which there is a row of stout hairs. An excellent photograph of the wings has been published by Esben-Petersen.

\section{Genus Neopanorpa Weele}

Including the three described below, twelve species of $\mathrm{Neo}$ panorpa are known from China.

Neopanorpa parva, n. sp.

Text-figures 3, 5 ; Plate 11, fig. 13.

Body: light to dark brown, darker on vertex, thoracic nota and abdominal tergites. Fore wing: length, 11-13 mm.; width, 
2-2.8 mm. (holotype, length, $11 \mathrm{~mm}$; width, $2 \mathrm{~mm}$.) wing membrane hyaline, markings gray-brown; apical band broken posteriorly; pterostigmal band wide and forked posteriorly; basal band reduced to a few spots. $\%$ : subgenital plate slender
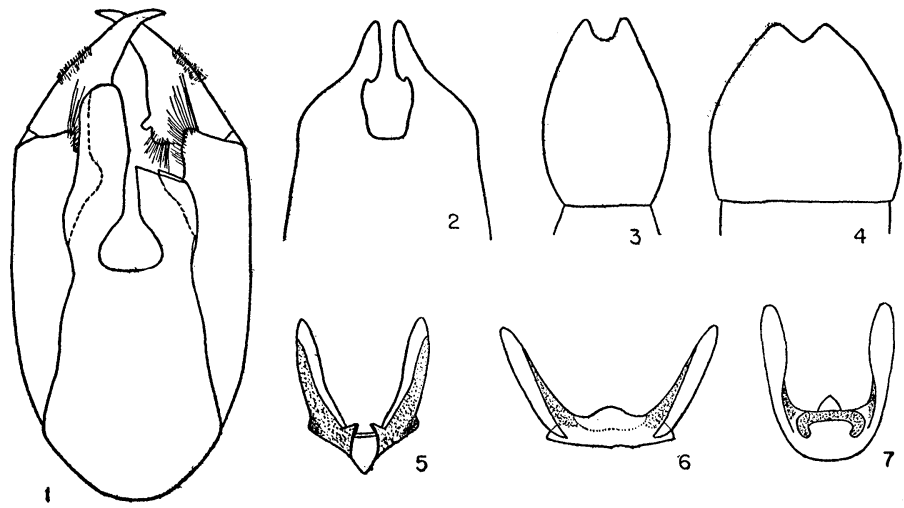

Text-figures 1-7. Fig. 1. Neopanorpa pilosa, n.sp., ventral view of male genital bulb (holotype). 2. Neopanorpa pilosa, n.sp., distal part of preëpiproct of male (holotype). 3. Neopanorpa parva, n.sp., subgenital plate of female (holotype). 4. Neopanorpa cavaleriei Navas, subgenital plate of female. 5. Neopanorpa parva, n.sp., internal skeleton of ninth abdominal segment of female (holotype). 6. Neopanorpa pulchra, n.sp., internal skeleton of ninth abdominal segment of female (holotype). 7. Neopanorpa cavaleriei Navas, internal skeleton of ninth abdominal segment of female.

with a narrow distal incision; internal skeleton of ninth abdominal segment small, with nearly parallel arms and very short axis. ô unknown.

Holotype ( 9 ): Museum of Comparative Zoology, no. 27327. Kwanshien, Szechwan Province, China, July 16, 1937 (G. Liu).

Paratypes: $4 \%$, same collecting data as the holotype; in Museum of Comparative Zoology.

This species has wing markings resembling those of $N$. $c a-$ valeriei Navas, but it is much smaller than the latter and the wing membrane is hyaline, not yellowish.

\section{Neopanorpa cavaleriei Navas Text-figures $4,7$.}

Neopanorpa cavaleriei Navas, 1908, Mem. Real. Acad. Cienc. Barc., 1908: 415, fig. 23. Esben-Petersen, 1921, Coll. Selys, 5(2): 83, fig. 93, 94.

I have determined as this species one female from Yim Na San, East Kwantung Province, June 16, 1936 (L. Gressitt). It 
is the same size and has the wing markings and color of the male of type, which I examined in the Muséum National in Paris. The type locality of cavaleriei is Kweiyang, Kweichow Province, some 600 miles from East Kwantung, but Navas has also recorded the species from Tonkin, Indo-China, and "Tibet." The subgenital plate of the specimen from Yim Na San is shown in figure 4, and the internal skeleton in figure 7. The latter is somewhat like that of parva, but has blade-like and twisted arms. The wing membrane and markings of cavaleriei are similar to those of the Formosan N. opthalmica Navas, but the internal skeletal plate of the female of opthalmica, which is well represented in the Museum of Comparative Zoology, is very different from that shown in figure 7.

\section{Neopanorpa pulchra, $\mathrm{n}$. sp.}

Text-figure 6; Plate 11, fig. 12.

Body light brown, slightly darker above. Fore wing: length, $14 \mathrm{~mm}$; width, $3 \mathrm{~mm}$. Membrane hyaline, markings graybrown. Apical band wide and entire, contiguous with pterostigmal band along costal margin; pterostigmal band wide, with a short fork posteriorly; basal band entire. Subgenital plate like that of parva but with a more shallow distal notch. Internal skeleton broader than long with widely divergent arms and no axis. ô unknown.

Holotype ( $q$ ): Museum of Comparative Zoology, no. 27328. Ta Han, Hainan Island, Kiangsi Province, June 23, 1935 (L. Gressitt).

There is a second specimen in the collection which almost certainly belongs to this species, but since the end of the abdomen has been broken off, I have not designated it a paratype. It was collected at Hong San, southeast Kiangsi Province, July 15, 1936 (L. Gressitt).

This species has the general wing pattern of parva but the wing is more slender and has more extensive markings. The internal skeleton differs in having widely divergent arms.

\section{Neopanorpa pilosa, n. sp.}

Text-figures 1,2

Body light brown, the vertex, thoracic nota and first four abdominal tergites dark brown. Male with the median process of the third abdominal tergite well developed, reaching almost 
to the anterior of the fourth segment. Fore-wing: length, 17.5 $\mathrm{mm}$.; width, $3.8 \mathrm{~mm}$. Wing membrane nearly hyaline, faintly smoky in appearance; no markings; pterostigma pale yellow. o genitalia: genital bulb slender, forceps rather short, outer margins gently curved, and with a large cluster of short black hairs near the middle; each of the forceps has a prominent lobe on the inner margin near the base, bearing a number of long black hairs; similar hairs arise from a short papilla on the genital bulb at the base of the forceps; hypovalvæ broad and long, reaching well beyond the base of the forceps; each is folded along the outer margin; preëpiproct with a pair of thick, distal processes, enlarged distally and directed inward towards the interior of the bulb. + unknown.

Holotype ( $\hat{o}$ ): United States National Museum. Suifu, Szechwan Province, China; 1000 ft. August 1928 (D. C. Graham).

This species bears some resemblance to nigritis Carp. but is much larger and has a lighter body. The male is readily distinguished by the long hypovalvæ and the patch of hairs on the forceps.

\section{Explanation of Plates \\ Plate 10}

Figure 1. Panorpa tetrazonia Navas, ventral view of male genital bulb.

Figure 2. Panorpa obliqua, n.sp., ventral view of male genital bulb, holotype.

Figure 3. Panorpa obliqua, n.sp., dorsal view of male genital bulb, holotype.

Figure 4. Panorpa davidi Navas, ventral view of male genital bulb, holotype.

Figure 5. Panorpa tetrazonia Navas, distal part of preëiproct of male.

Figure 6. Panorpa tetrazonia Navas, internal skeleton of ninth abdominal segment of female.

Figure 7. Panorpa lutea, n.sp., internal skeleton of ninth abdominal segment of female, holotype.

Figure 8. Panorpa obliqua, n.sp. internal skeleton of ninth abdominal segment of female, allotype.

\section{Plate 11}

The photographs do not indicate relative sizes.

Figure 9. Fore wing of Panorpa obliqua, n.sp., allotype.

Figure 10. Fore wing of Panorpa tetrazonia Navas.

Figure 11. Fore wing of Panorpa lutea, n.sp., holotype.

Figure 12. Fore wing of Neopanorpa pulchra, n.sp., holotype.

Figure 13. Fore wing of Neopanorpa parva, n.sp., paratype. 


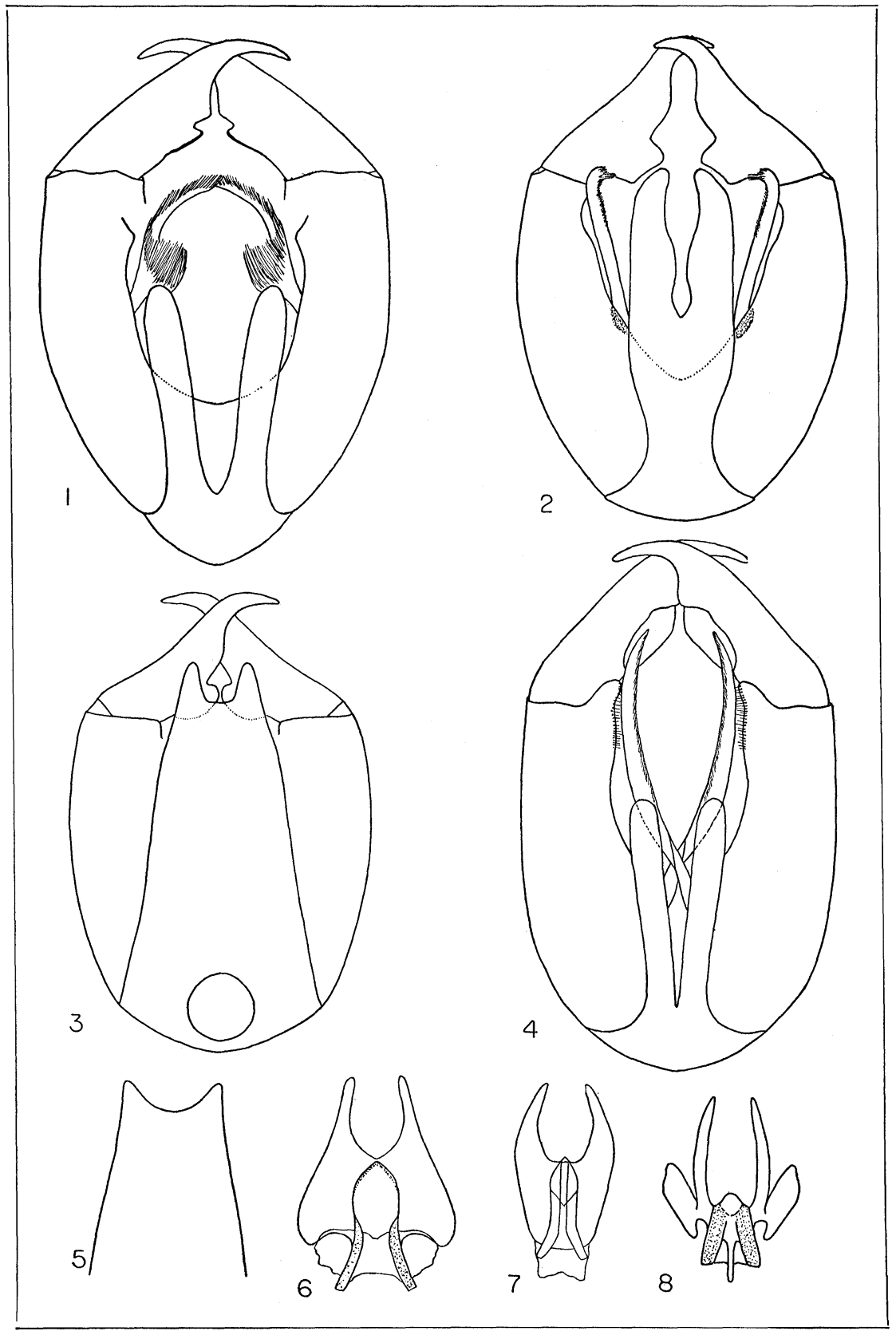

Carpenter - Panorpide from China 


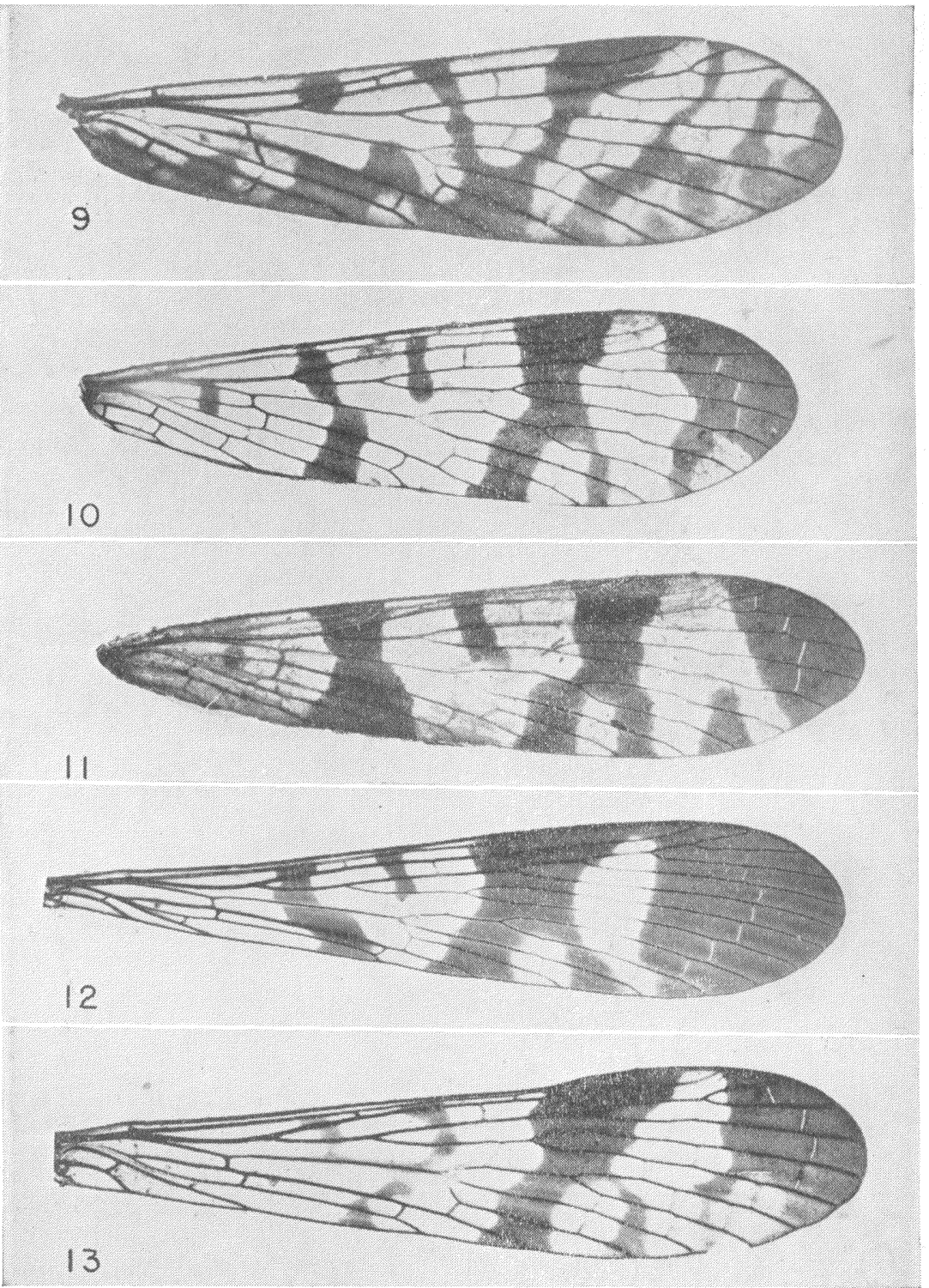

Carpenter - Panorpide from China 

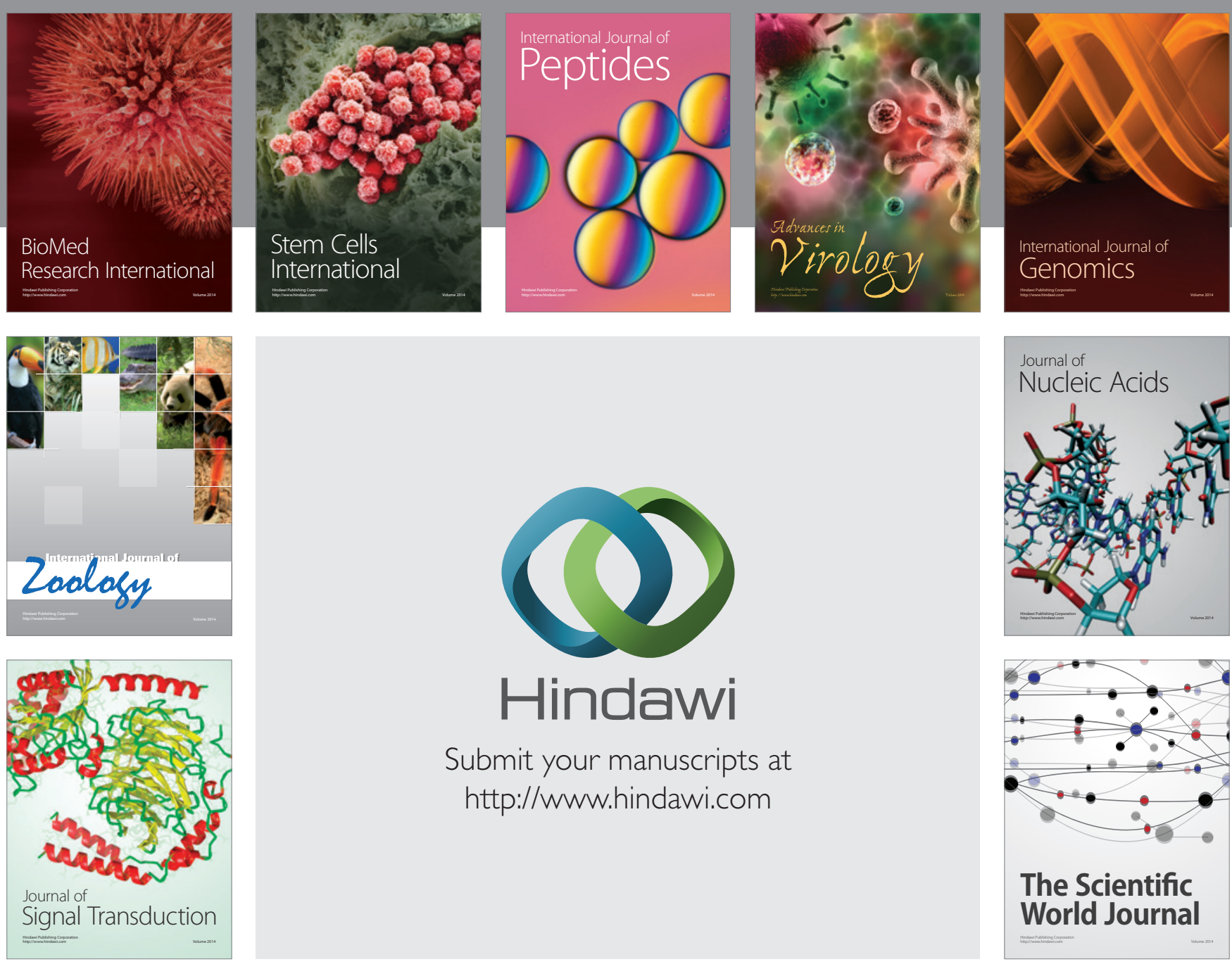

Submit your manuscripts at

http://www.hindawi.com
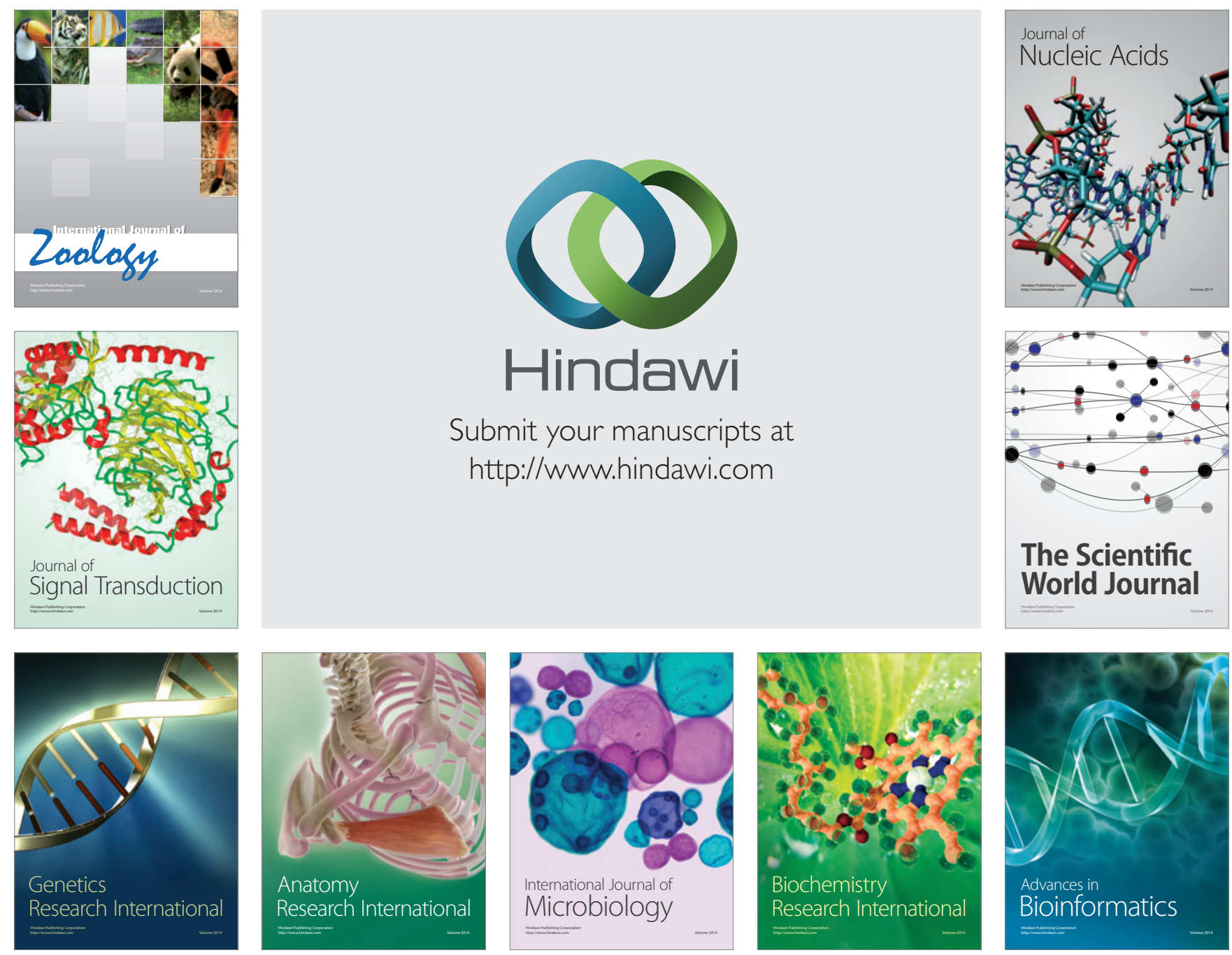

The Scientific World Journal
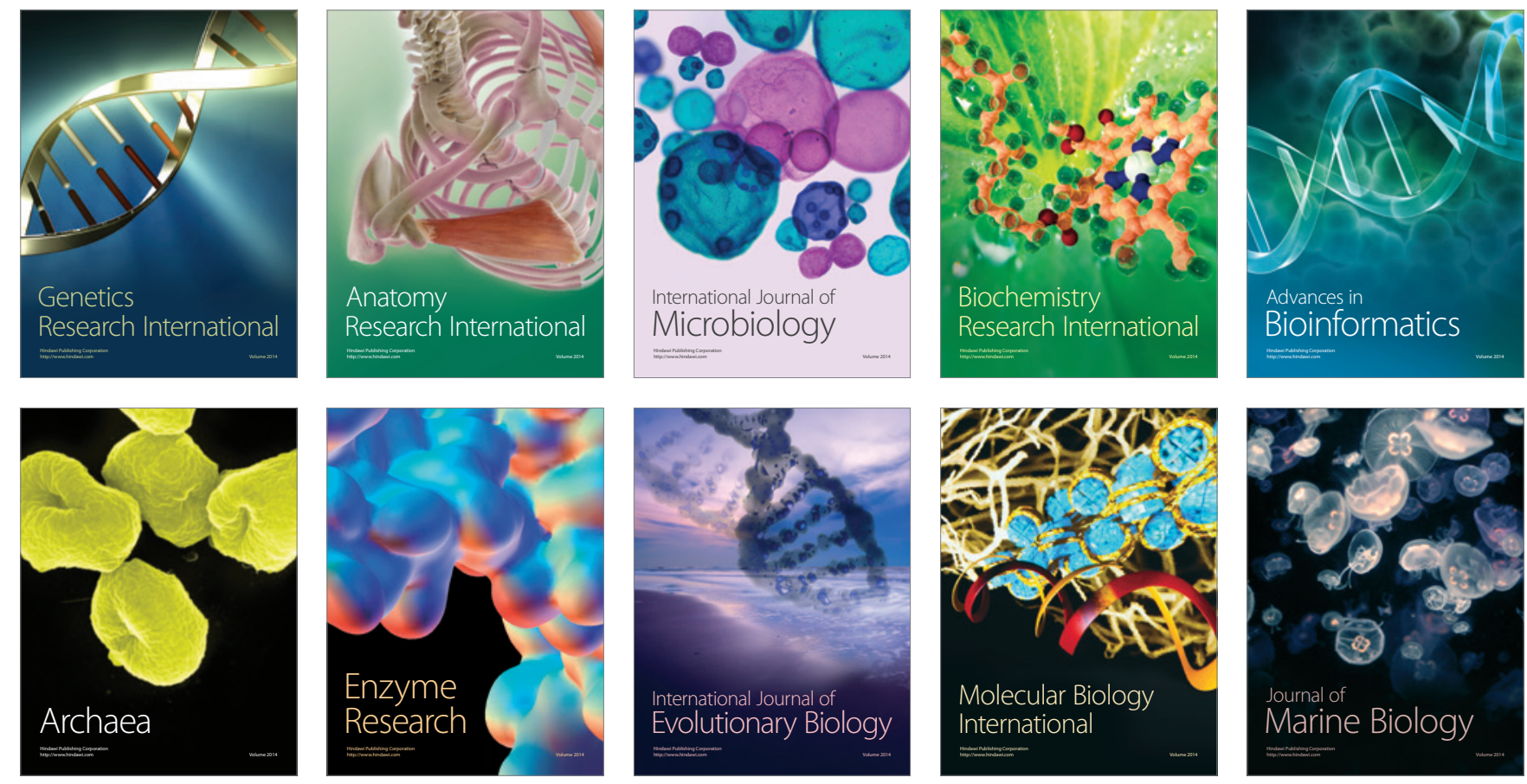